\title{
Influence of physical exercise on microRNAs in skeletal muscle regeneration, aging and diseases
}

\author{
Simona Ultimo ${ }^{1}$, Giorgio Zauli ${ }^{1}$, Alberto M. Martelli², Marco Vitale ${ }^{3,4}$, James A. \\ McCubrey ${ }^{5}$, Silvano Capitani ${ }^{1}$ and Luca M. Neri ${ }^{1}$ \\ ${ }^{1}$ Department of Morphology, Surgery and Experimental Medicine, University of Ferrara, Ferrara, Italy \\ ${ }^{2}$ Department of Biomedical and Neuromotor Sciences, University of Bologna, Bologna, Italy \\ ${ }^{3}$ Department of Medicine and Surgery, University of Parma, Parma, Italy \\ ${ }^{4}$ CoreLab, Azienda Ospedaliero-Universitaria di Parma, Parma, Italy \\ ${ }^{5}$ Department of Microbiology and Immunology, Brody School of Medicine, East Carolina University, Greenville, USA \\ Correspondence to: Luca M. Neri, email: luca.neri@unife.it \\ Silvano Capitani, email: silvano.capitani@unife.it \\ Keywords: skeletal muscle; regeneration; aging; physical activity; miRNAs \\ Received: December 21, $2017 \quad$ Accepted: March 06, $2018 \quad$ Published: March 30, 2018 \\ Copyright: Ultimo et al. This is an open-access article distributed under the terms of the Creative Commons Attribution License 3.0 \\ (CC BY 3.0), which permits unrestricted use, distribution, and reproduction in any medium, provided the original author and source \\ are credited.
}

\section{ABSTRACT}

Skeletal muscle is a dynamic tissue with remarkable plasticity and its growth and regeneration are highly organized, with the activation of specific transcription factors, proliferative pathways and cytokines. The decline of skeletal muscle tissue with age, is one of the most important causes of functional loss of independence in older adults. Maintaining skeletal muscle function throughout the lifespan is a prerequisite for good health and independent living.

Physical activity represents one of the most effective preventive agents for muscle decay in aging.

Several studies have underlined the importance of microRNAs (miRNAs) in the control of myogenesis and of skeletal muscle regeneration and function.

In this review, we reported an overview and recent advances about the role of miRNAs expressed in the skeletal muscle, miRNAs regulation by exercise in skeletal muscle, the consequences of different physical exercise training modalities in the skeletal muscle miRNA profile, their regulation under pathological conditions and the role of miRNAs in age-related muscle wasting.

Specific miRNAs appear to be involved in response to different types of exercise and therefore to play an important role in muscle fiber identity and myofiber gene expression in adults and elder population.

Understanding the roles and regulation of skeletal muscle miRNAs during muscle regeneration may result in new therapeutic approaches in aging or diseases with impaired muscle function or re-growth.

\section{INTRODUCTION}

Skeletal muscle upholsters the important role of supporting skeletal structure and movement and it is also involved in glycogen synthesis and amino-acid deposits $[1,2]$. A general physical performance is improved by exercise that induces molecular and cellular adaptations [2]. Metabolism of muscle and its homeostasis are due to protein synthesis/degradation and activity of muscle stem cells, whereas the synthesis and degradation of total muscle protein is due principally to nutrition and physical activity seems to act on both protein synthesis/degradation and on satellite cells [2].

At the entire muscle level, hypertrophy is the major consequence of physical exercise that can be produced both by new satellite cell fusion or by amplified protein synthesis [3]. 
Likely, satellite cells are stimulated when an acute stimulus occurs (i.e. strong exercise with eccentric contractions, that is a motion of an active muscle while it is lengthening under load) and leads to hypertrophy enhancing the number of myonuclei and their fiber size, thus imitating the regeneration pathway in response to injury [4]. Nevertheless, moderate physical activity does not stimulate satellite cells and functional overload leads to a muscle growth solely through protein synthesis $[2,5]$.

Physical activity is a term used to describe any physical training developed by skeletal muscles that requires energy cost, which may be unstructured and everyday life motion. The term exercise includes prearranged, deliberate and repetitive motion and ordinary sports and agonistic sports [6].

In chronic degenerative diseases, physical activity is one of the most efficient protective agents and it has been suggested as effective therapy for chronic diseases such as for example osteoarthritis and claudication [7].

Actually, both at genomic and post-genomic levels, a regular physical activity exerts a relevant effect on different parameters and biological pathways [8].

microRNAs (miRNAs) are a class of small noncoding RNAs (around 21-25 nucleotides) that play a role in modulation of gene expression at the posttranscriptional level by inhibiting translation or leading to RNA degradation $[2,9]$. In health prevention there is an increasing attention to know more markedly the processes involved in stimulation and inhibition of miRNAs expression. Several miRNAs are essential as mediators of processes associated with exercise training adaptation including cardiac and skeletal muscle hypertrophy and regeneration in adulthood and elder population. Recently it has been shown the effects of regular sport exercise on miRNAs regulation. In addition, miRNAs seem to play important roles in the acute and chronic resistance training (RT), endurance training (ET), in athletes, in animal models, in patients and in the general population [10] and regulation of miRNAs, controlled by physical activity in human skeletal muscle, depends on variety, intensity and duration of the training.

Aging is associated with alterations in skeletal muscle size, structure and function, that may lead to muscle atrophy with increased morbidity and mortality.

During tissue aging, it is well known that both stem cell number and function are reduced [11].

Muscle growth and increased strength is the result of progressive resistive training in older individuals, if the training stimulus is of an adequate intensity and duration. Endurance physical activity in aged, where the stimulus is repeatedly enhanced, evokes a development of muscle capillaries, enhances oxidative enzyme activity, and induces important amelioration of maximal oxygen consumption $\left(\mathrm{VO}_{2} \max \right)[12]$.
Despite a quite large and increased number of studies on miRNAs in skeletal muscle and aging during physical exercise, an analysis that summarized these results has not been already described.

With this review we aim to overview how acute or chronic physical exercise influences miRNA expression and whether the variability of muscle hypertrophy in response to exercise may be attributed to differential miRNA regulation in the skeletal muscle. We describe how miRNAs are differentially expressed in elder age at the baseline condition and the relevance of physical activity.

\section{SKELETAL MUSCLE REGENERATION AND PHYSICAL EXERCISE}

\section{Aspects of myogenesis}

A complex and multi-stage process involving many regulators is named myogenesis. The myogenic progenitor cells confer to proliferating cells commitment to the myogenic lineage (myoblasts) [13]. The process of myogenesis is determined by the myogenic regulatory factors (MRFs) that include four key transcription factors: Myf5, MyoD, Myogenin (MyoG) and Myf4 regulating the differentiation of muscle cells. The determinants of myogenesis are Myf5 and MyoD whereas MyoG and Myf4 are greatly expressed during the terminal differentiation and they drive myoblasts fusion forming myotubes [13].

Paired-domain- and homeobox-containing proteins are upstream regulators of early MRFs, including Pax3 and Pax7, which are in action in embryogenesis. When myoblasts move, MyoG and MRF4 are expressed and drive myoblasts to differentiate to myotubes. They operate in concert with other factors following the terminal differentiation into myotubes, including myocyte enhancer factor 2 (MEF2) [14, 15] (Figure 1). Mesoderm-derived structures create the first muscle fibers of the body proper during embryonic myogenesis and consequently waves of additional fibers are created along these template fibers $[16,17]$.

As described below these transcription factors and regulatory proteins are again involved during muscle regeneration processes.

\section{The muscle regeneration process and skeletal muscle stem cells}

During embryogenesis muscle regeneration after damage or physical training has analogies to muscle development [18].

Skeletal muscle restore is a very synchronized mechanism including the stimulation of different molecular and cellular responses. In addition the coordination among inflammation and regeneration is critical for the positive result of the repair mechanism 
following muscle injury [19]. Muscle tissue restore can be described as a mechanism following injury consisting of two interdependent phases, degeneration and regeneration, whose successful outcome in muscle repair appears to be affected by the level of the injury and the interactions among muscle and infiltrating inflammatory cells.

A balance among pro-inflammatory and antiinflammatory factors is correlated to muscle regeneration process that decides whether the injury will be resolved with muscle fiber change and regeneration of a functional contractile apparatus, or with scar formation [18]. The phases of the recovery mechanism are analogous in various causes of injury, and the kinetics and amplitude of each phase may depend on the kind of muscle injuried and the area of injury [18].

The main stem cell pool of adult skeletal muscle are represented by satellite cells [20]. These cells, which were first described by Mauro (1961) [21], represent undifferentiated myogenic precursor cells that lie between the external lamina and sarcolemma of skeletal muscle fibers. Under normal conditions, satellite cells are quiescent, but with appropriate environmental signals they become activated and enter again into the cell cycle to either create novel muscle fibers or supply novel myonuclei to the parent fiber [22, 23]. Studies about genetic ablation and transplantation taken jointly confirmed that Pax7+ satellite cells are required for adult muscle restore [24-26], in response to muscle injury. Satellite cells transition from their normally quiescent state to initiate the cell cycle, expand and differentiate (exiting again from the cell cycle) thus forming novel muscle fibers and regenerating the damaged muscle tissue [27].

An increase in the number of satellite cells is necessary for full skeletal muscle growth and hypertrophy, therefore, the majority of the regeneration process is an orderly sequence of activation, proliferation and differentiation of satellite cells.

Quiescent satellite cells are present throughout the muscle, but the distribution of satellite cells has been shown to vary between different individuals and between different muscle groups and muscle fiber types [28]. Muscles containing mainly type I fibers are very resistant to fatigue and capable of producing repeated low-level contractions (e.g. soleus muscle [29]), type II fibers, known also as fast glycolytic fibers, produce instead fast and strong muscle contractions (e.g. extraocular eye muscle, arm muscles) [30]. The population of satellite cell is not constant: it has been shown to increase after low-frequency exercise and in neuromuscular diseases such as Duchenne muscular dystrophy and neurogenic atrophy, while it has been reported to decrease in olderly men and women compared with a younger population [31]. The signaling pathways for satellite cell activation are not fully understood, but several mediators such as growth factors, nitric oxide (NO), mechanical stimulation and physiological stimuli induced by exercise have been suggested. Identification of satellite cells

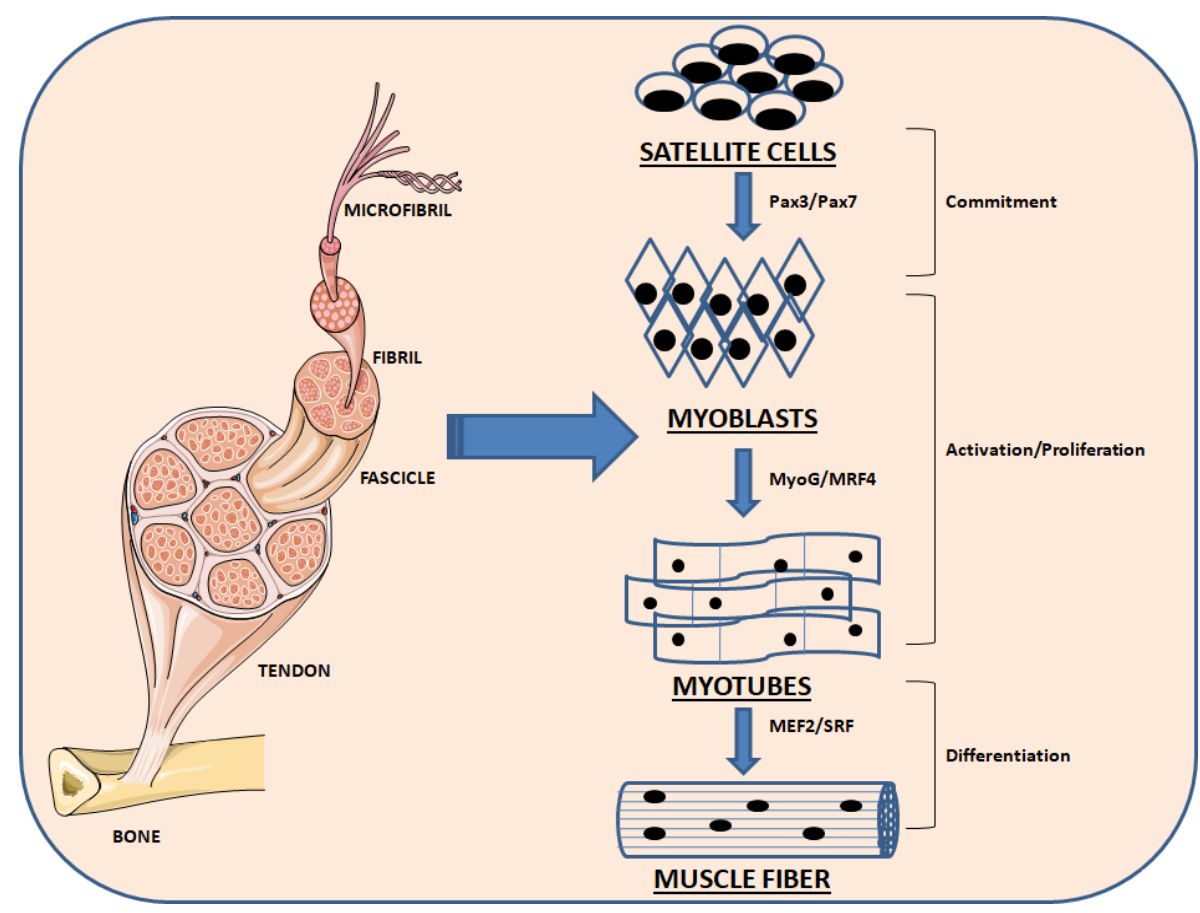

Figure 1: Schematic representation of the myogenesis process. Quiescent skeletal muscle satellite cell can become activated following stimuli. The skeletal myoblasts, express transcriptions factors Pax7 and Pax3, as well as the myogenic regulatory factors Myf5 and MyoD. Once committed to differentiation, myoblasts arrest cycling and loose expression of Pax7, Pax3 and Myf5. MRF4 is further required for hypertrophy of the new fibers. 
has commonly been done using electron microscopy and immunohistochemical identification, identifying a cell-surface, membrane-bound neural cell adhesion glycoprotein (N-CAM) [32].

\section{THE RESPONSE OF SKELETAL MUSCLE REGENERATION TO DIFFERENT PHYSICAL TRAININGS: RESISTANCE AND ENDURANCE}

A series of changes in the molecular and structural properties of skeletal muscle are promoted by physical activity, including changes in mitochondrial biogenesis and metabolism, enhanced muscle vascularization and the modulation of myofibrillar content [33, 34]. These alterations are often related to the amelioration of wholebody aerobic ability [35] and although its a greatly adaptable ability, the skeletal muscle could react in different ways to resistance and endurance physical training [34].

Resistance training (RT) is defined as any physical activity that lead to muscle contraction against an external resistance with the expectation of boost in strength, tone and mass. As external resistance, objects can be used such as dumbbells, rubber exercise tubing, your own body weight, bricks, bottles of water, or any other object that leads to muscle contraction to win an external resistance including gravity force [36]. Usually, resistance exercises happen in short bouts with rest periods between each set and are anaerobic.

Endurance training (ET) is the act of exercising to increase endurance, in other words, the ability to keep doing something difficult, unpleasant, or painful for a long time. The term endurance training generally refers to training the aerobic system as opposed to the anaerobic system [37]. Incresed capillarization, amelioration in energy metabolism, mitochondrial biogenesis and the transformation of fast-toslow fiber type can be caused by ET, whereas RT elicits to the biosynthesis of contractile and structural proteins, leading to muscle hypertrophy and increased generation of contraction force [34].

Resistance and endurance exercise training enhances the satellite cell pool [38]. It was also demonstrated that an increase in the satellite cell pool of skeletal muscle, following ET, depends on the intensity rather than duration of exercise [38]. However, it is not fully clear which factors could induce increase in the proliferative potential of satellite cells by physical training. Skeletal muscle has been acknowledged as a cytokine producing organ during muscular exercise, the so called myokines. To date, the list of identified myokines includes IL-6, IL-7, IL-8, IL15 , leukemia inhibitory factor (LIF), Irisin [39], fibroblast growth factor 21 (FGF 21) and brain-derived neurotrophic factor (BDNF) [40, 41]. Some myokines have the potential to modulate satellite cell proliferation. Previous research showed that dramatic increase in plasma IL-6 and LIF were observed after endurance exercise [42]. Kurosaka et al (2012) [38] confirmed that IL-6 may induce a dosedependent increase of satellite cells through activation of janus kinase (JAK)/signal transducer and activation of transcription 3 (STAT3)/Cyclin D1 pathway that promotes cell cycle activation.

RT exercises increase the cross sectional area (CSA) of the whole muscle together with individual muscle fibers myofibrillar dimension and quantity [43]. The hypertrophy response to RT is associated with the stimulation of early stage satellite cells and may also promote other changes, such as hyperplasia, modifications in muscle fine structure, in myofilament density and in the connective tissue structure [43]. Structural transformations in skeletal muscle during RT are fiber specific: fast-twitch (FT) fibers are more sensitive to injury than slow-twitch (ST) ones [44]. Damage caused by RT in skeletal muscle has been clarified to be also a stimulus for muscle regeneration since it promotes signaling events arised from fiber mechanical deformation, immune/inflammatory responses and hormones production [44]. The synthesis rate of myofibrill is enhanced by RT but not by sarcoplasmic proteins [45].

An age consequence is a slower recovery from RT damaging, whereas recovery from small damaging metabolic fatigue did not report age-related difference [46]. RT increased the level of insulin-like growth factor 1 (IGF-1) and of mechano growth factor (MGF) in skeletal muscle and faster recovery of muscle tissue is supported by both these elements [47].

ET exercises is responsible of most modifications in muscle fibers type I and IIA. The day after ET, important injurious modifications can be observed in these fiber myofibrils. This injury involves the decay of myosin and actin filaments and the regularity of Z-line in some sarcomeres. Myosin filaments were absent after ET in some A-discs and the injurious stress may influence the whole sarcomere. In response to ET 5' adenosine monophosphate protein kinase (AMPK) is activated and is associated to skeletal muscle metabolic adaptation. AMPK function involves glucose transport, glycogen metabolism, fatty acid oxidation and structural muscle genes transcriptional regulation [48]. AMPK $\alpha 1$ isoform regulates skeletal muscle growth and $\alpha 2$ isoform controls its metabolic adaptation [49].

Protein change in skeletal muscle is quite slow. Myosin heavy chain (MyHC) and myosin light chain (MyLC) isoforms change rate provides a process by which the kind and quantity of protein is modified in agreement with the necessities of the contractile machinery during adaptation to ET. ET increase the satellite cell number mainly under the basal lamina of type I and IIA fibers and increase their regeneration capacity [50]. 


\section{miRNA FUNCTIONS IN SKELETAL MUSCLE REGENERATION}

To identify the function and modulation of skeletal muscle miRNAs during different phases of muscle regeneration, in healthy and pathological status, will increase our knowledge of skeletal muscle biology significantly and may result in novel treatments in aging and pathologies related with damaged muscle development, regeneration or activity [51].

miRNAs provide a key and powerful tool in gene regulation in several cellular roles such as progression, differentiation, growth and metabolism. Up to date around 2200 miRNA genes have been described in the mammalian genome [52, 53].

Several miRNAs, greatly enriched in cardiac and/or skeletal muscle (named myomiRs), has been determined and involve miR-1, miR-133a, miR-133b, miR-206, miR208, miR-208b, miR-486 and miR-499 (Figure 2) [54-57].

Many of these miRNAs (i.e. miR-1-1/133a-2, miR1-2/133a-1 and miR-206/133b) are distributed under bicistronic clusters on the same chromosome and are transcribed together [58].

MyomiRs regulation is under the control of MRFs, including MyoD and MyoG $[59,60]$ as well as by MEF2 [61], SRF [62] and myocardin-related transcription factor-A (MRTF-A) [56]. MyomiRs affect several facets of muscle growth and role, regulating key genes controlling myogenesis [59, 62]. Despite miR-1 and miR-133 tissuespecific expression is driven by MyoD and SRF, miR-
133 inhibits SRF expression. In this way, these results recognize a negative regulatory loop in which miRNAs take part to cellular proliferation and differentiation control. Myogenesis is promoted by miR-1 targeting histone deacetylase 4 (HDAC4), a transcriptional repressor of muscle gene expression (Table 1), whereas myoblast proliferation is increased by miR-133 inhibiting SRF [62]. Aberrant regulation of some of these muscle-enriched miRNAs could disrupt intracellular signaling networks $[56,63]$ which may result in pathological conditions (e.g. muscular dystrophies) [64].

Satellite cells and adult muscle stem cells show various sets of miRNAs during quiescence or activation, contributing to muscle regeneration, suggesting miRNA roles in controlling satellite cell homeostasis [65]. In addition, during either physical activity and aging, the expression profile of miRNAs in satellite cells and muscle is modified [66]. The generation of novel muscle fibers and the restore of damaged myofibers (a process that lead to formation of muscle tissue) need the differentiation of myogenic progenitors or satellite cells respectively and many miRNAs have been demonstrated to control muscle regeneration in adulthood, involving miR-1, miR-206, miR-27, miR-378 and miR-181 (Figure 2) [66, 67].

The Pax3 expression is downregulated when satellite cells/myogenic progenitors are activated. If MyoD expression is increased, the $\mathrm{Pax} 3 / \mathrm{Pax} 7$ expression downregulation is partially mediated by miR-1 and miR-206, warranting total inhibition of Pax genes to achieve synchronisation of myogenesis regeneration

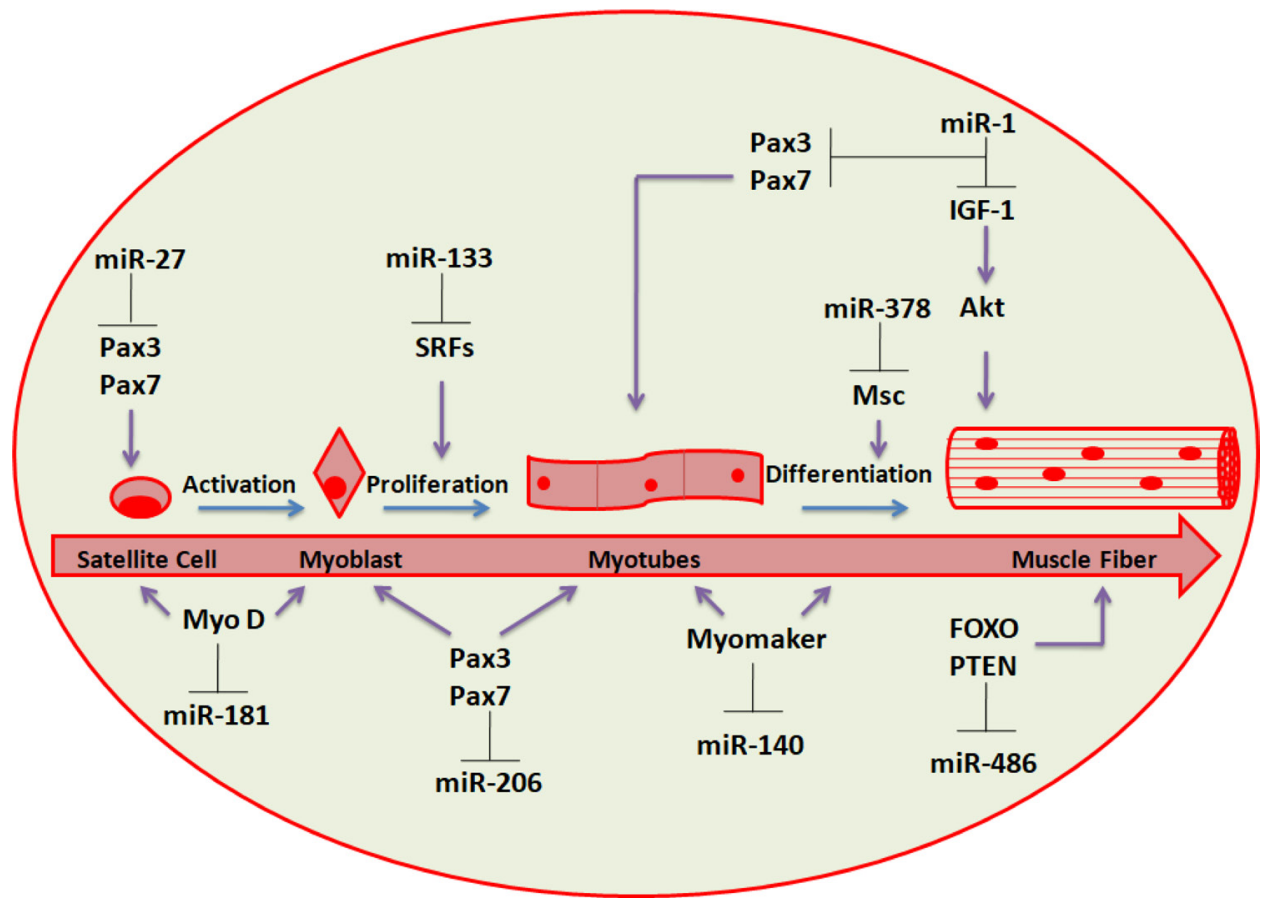

Figure 2: miRNAs involved in skeletal muscle regeneration. Schematic representation of the differentiation stages leading from progenitor muscle cells to terminally differentiated fibers. The most relevant regulatory circuits between miRNAs and protein factors are shown. 
Table 1: Summarized list of the most studied miRNAs with their target genes and the type of exercise involved

\begin{tabular}{|c|c|c|c|}
\hline miRNA & Main target & Type of exercise involved & References \\
\hline $\operatorname{miR}-1$ & $\begin{array}{c}\text { HDAC4; } \\
\text { Pax3/Pax } 7 \\
\text { Cyclin D1. }\end{array}$ & $\begin{array}{c}\text { Acute and Chronic Endurance } \\
\text { Training }\end{array}$ & $\begin{array}{l}\text { van Rooij E. et al.,2009; } \\
\text { Margolis LM. et al. } 2017 .\end{array}$ \\
\hline $\operatorname{miR}-21$ & $\begin{array}{c}\text { PTEN, } \\
\text { SPRY-1, ERK/MAP }\end{array}$ & $\begin{array}{c}\text { Acute and Chronic Endurance } \\
\text { Training }\end{array}$ & $\begin{array}{l}\text { Iwasaki H. et al., 2015; } \\
\text { Shen L. et al., } 2016 .\end{array}$ \\
\hline $\operatorname{miR}-126$ & RAAS, VCAM-1 & $\begin{array}{c}\text { Acute and Chronic Endurance } \\
\text { Training }\end{array}$ & $\begin{array}{l}\text { Kim E. et al. 2012; } \\
\text { Shen L. et al., } 2016 .\end{array}$ \\
\hline $\mathrm{miR}-133 \mathrm{a} / \mathrm{miR}-133 \mathrm{~b}$ & $\begin{array}{c}\text { CALM1, } \\
\text { SRF, } \\
\text { PTBP2, } \\
\text { SP1. }\end{array}$ & $\begin{array}{l}\text { Acute resistance exercise } \\
\text { Chronic training, Chronic } \\
\text { resistance exercise }\end{array}$ & $\begin{array}{c}\text { Masi LN. et al., 2016; } \\
\text { Margolis LM. et al., } 2017 .\end{array}$ \\
\hline $\operatorname{miR}-181 \mathrm{a}$ & $\begin{array}{l}\text { SIRT1, } \\
\text { PTEN, } \\
\text { NFATC1. }\end{array}$ & $\begin{array}{c}\text { Acute and Chronic Endurance } \\
\text { Training }\end{array}$ & $\begin{array}{c}\text { Silva GJJ. et al., 2017; } \\
\text { Margolis LM. et al., } 2017 .\end{array}$ \\
\hline miR-206 & $\begin{array}{c}\operatorname{Pax} 3 / \operatorname{Pax} 7 \\
\text { BDNF, } \\
\text { HDAC4. }\end{array}$ & $\begin{array}{c}\text { Acute and Chronic Endurance } \\
\text { Training }\end{array}$ & $\begin{array}{l}\text { Nielsen S. et al., 2010; } \\
\text { Nielsen S. et al., } 2014 .\end{array}$ \\
\hline
\end{tabular}

(Table 1) [68]. Moreover, miR-206 and miR-486 have been demonstrated to cause myoblast differentiation by downregulating Pax7 expression and Pax3 expression is inhibited by miR-27 in satellite cells during regeneration process $[66,69,70]$.

MyoD activation contributes to the upregulation of several miRNAs expression during myogenesis, including miR-378, an inhibitor of mesenchymal stem cell (Msc) proliferation [71]. miR-378 may strengthen the formation of muscle fibers by silencing Msc expression in the advanced phases of the differentiation process [66]. Interestingly, miR-378 is encoded within an intron of the peroxisome proliferator-activated receptor gamma coactivator 1-beta (Ppargc1 $\beta$ gene) that encodes for PGC-1 $\beta$, a controller of energy metabolism. It has been suggested that miR-378 is co-expressed with PGC-1 $\beta$, and it has been confirmed that it play a role in metabolism and interactions with target genes [66]. Gagan et al. (2011) showed that miR-378 is upregulated by MyoD during myogenic differentiation in immortalized mouse myoblast (C2C12) cells [72]. Chromatin immunoprecipitation (ChIP) and high throughput sequencing studies showed that MyoD is located close to miR-378 gene and leads to both transactivation and chromatin remodeling.

Transcriptional activity of MyoD is increased by miR-378 [73], partially by inhibiting MyoR that is an antagonist. The MyoR 3' untranslated region (UTR) has a direct linking site for miR-378 and the presence of this linking site reduced the MyoR capacity to avoid the MyoD-driven transdifferentiation of fibroblasts notably.

\section{miRNA expression associated to muscle regeneration induced by physical activity}

Exercise affects skeletal muscle and it was also recently shown it is capable to modify skeletal muscle miRNA expression [74, 75].

A group of young and adult males underwent for 12 weeks to resistance physical training separating the group into "low-responders" and "high-responders" based on each subject's modifications in lean body mass [76, 77]. In this study it has been analyzed if expression levels of the most expressed miRNAs varied among the two groups. It has been profiled twentyone miRNAs, demonstrating that miRNA expression was not influenced in the vastus lateralis muscle in the high-responder group whereas the low-responder group showing an important modification in miR-451 and miR-378, with a downward tendency for miR-26a and miR-29a in the vastus lateralis muscle. miR-378 upregulation expression demonstrated an important association with lean body mass, leading the authors of this study to hypotesize that the expression of significant miR-378 levels were necessary for a lean body mass increase [76, 77]. In vitro data supported the idea that miR-378 contributes to myoblast differentiation by targeting MyoR, a negative controller of the myogenic transcription factor MyoD [77, 78]. Moreover, currently miR-378 has been demonstrated to regulate mitochondrial metabolism and bioenergetics via the modulation of PGC1- $\beta$, and its increased expression 
would likely be a normal condition as a consequence of endurance exercise [77, 79].

These data suggested that miRNAs play an important role in regulating the translation of key pathways responsible for skeletal muscle growth in response to RT in high and low responder individuals.

Ceccarelli et al (2017) showed that, 4 hours postexercise, only a resistance exercise followed by cycling (a combination of anaerobic and aerobic exercise) caused an important boost in miR-23a-3p ( 90\%), miR-23b-3p ( 39\%), miR-133b ( 80\%), miR-181-5p ( $\sim 50 \%)$, and miR-378-5p ( 41\%). A recent review reported gene expression regulations by exercise-related miRNAs $[2,80]$. miRNA targets have been reported to be: 1) signaling transduction pathways controlled by calcium and activated protein kinase (AMP); 2) class IIa histone deacetylases; 3) muscle specific transcription factors (i.e. $\mathrm{MyoD}, \mathrm{MyoG}$ ); 4) mitochondrial targets mtTFA and FoxJ-3/MEF-2); 5) mitogen-activated protein kinases (MAPKs); 6) Run 1, Sox9, Pax3; 7) vascular endothelial growth factor (VEGF) and IGF-1 (Table 1) [2]. Taken together these findings evidenced a role for miRNAs in muscle metabolism modulation by physical training $[2,81]$.

myomiRNAs play an important role in the skeletal muscle adaptations to ET in both human health and diseases. ET can modify the levels of several miRNAs, e.g. miR-1, miR-16, miR-21, miR-26a, miR-29a, miR126, miR-133a, miR-133b, and miR-206, miR-378, miR451 and miR-494. Coordinated changes in the expression levels of these myomiRNAs contribute to skeletal muscle adaptations to acute and chronic ET. miRNAs can mediate the ET-induced changes in the skeletal muscle phenotype and exercise can rapidly and transiently regulate several miRNAs in the skeletal muscle.

Russell and colleagues (2013) have performed measurements in muscle biopsies of healthy men not practicing sports, after only one moderate-intensity endurance cycling or after chronic cycling ET [82]. They found a rise in muscle-augmented miRNAs, involving miR-1, -133a and 133-b, as well as miR-181a and in parallel the decrease of miR-9, -23a, -23b and -31 ; the latter miRNAs categories are increased in different muscle wasting diseases [82].

After short-term exercise of 10 days miR-1 was found upregulated, instead miR-29b and -31 were found downregulated [82]. Either loss- and gain-of-function experiments have shown that miR-208b and miR-499 play important roles in muscle fiber identity by activating slow and repressing fast myofiber gene program $[82,83]$. Several other studies have shown that after 3 hours of one acute exercise miR-1, miR-133a, miR-133-b and miR181a were all increased $[10,84,85]$ whereas, miR-9, miR23a, miR-23b and miR-31 decreased (Table 2). In another study, Nielsen and colleagues (2010) demonstrated that miR-1 and miR-133a expression levels in the vastus lateralis of healthy individuals were significantly upregulated after only one cycle ergometer activity at $65 \%$ of maximal power (Pmax). On the other hand, 12 weeks of ET on a cycle ergometer resulted in a decrease in the miR1, miR-133a, miR-133b, and miR-206 [86-91]. Likewise, Keller et al (2011) showed that 6 weeks of cycling reduced the expression of miR-1 and miR-133 with miR-101 and miR-455 in human skeletal muscle [77, 92].

Data suggested that miRNA expression levels could modify following exercise status in order to control exercise adjustments [77].

Interestingly, miR-1 and miR-133, clustered on the same chromosomal loci, are transcribed together in a tissue specific manner during development and have distinct roles in the modulating skeletal muscle proliferation and differentiation [10]. Furthermore miR-1 and miR-133 are both implied in cardiac and skeletal-associated human disorders [93]. These results showed that these mature miRNAs, originated by the same miRNA polycistron and transcribed together, can perform different biological roles.

Other analysis showed that ET can modify the levels of several miRNAs expressed in skeletal muscle, such as miR-1, miR-16, miR-21, miR-26a, miR-29a and miR-126 [94, 95] (Table 2). In addition, changes has been reported in skeletal muscle miRNA expression such as miR-136, miR-200c, miR-376, miR-377, miR-499b and miR-558. These miRNAs were up-regulated after chronic resistance exercises (i.e. leg press, leg curl, etc.) while, several miRNAs, such as miR-28, miR-30d, miR-204 and miR-330 were on the contrary down-regulated [96] (Table 2). Taken together, the studies reported suggest that myomiRNAs play an important role in the skeletal muscle adaptations to ET in human health and that coordinated changes in the expression levels of these miRNAs contributed to skeletal muscle adaptations to acute and chronic ET.

\section{miRNA expression in skeletal muscle disorders}

miRNAs are fundamental modulators of skeletal muscle health and it is of high interest their involvement in the onset and development of myopathies and chronic disorders related with muscle wasting and dysfunction [74].

Primary skeletal-muscle diseases include a cohort of pathologies, such as muscular dystrophies, inflammatory myopathies and congenital myopathies. Although every year the gene numbers implied in muscle diseases rise and histological pathology of disorder tissue is widely reported, the essential molecular mechanisms continue to be little described [97]. The most often inherited neuromuscular disease in adults is myotonic dystrophy type 1 (DM1) and in a study it has been demonstrated that miR-206, a regulator of muscle regeneration, was especially increased in patients affected by DM1 when compared to healthy individuals [98]. Furthermore miR-1 and miR-335 are 
Table 2: Sport exercise affect skeletal muscle miRNA expression

\begin{tabular}{|c|c|c|c|}
\hline $\begin{array}{l}\text { miRNA } \\
\text { upregulated }\end{array}$ & miRNA down regulated & $\begin{array}{c}\text { Type } \\
\text { of exercise }\end{array}$ & References \\
\hline \multirow{2}{*}{$\begin{array}{l}\operatorname{miR}-1, \text { miR-133a, } \\
\text { miR-133b, miR181a }\end{array}$} & miR-9, miR-23a, miR-23b, miR-31 & Acute exercise & Russell AP. et al., 2013. \\
\hline & $\begin{array}{l}\operatorname{miR}-1, \operatorname{miR}-23 a, \operatorname{miR}-133 a, \operatorname{miR}-133 b \text {, } \\
\text { miR-206 }\end{array}$ & $\begin{array}{l}\text { Acute resistance } \\
\text { exercise, Chronic } \\
\text { training, Chronic } \\
\text { resistance } \\
\text { exercise }\end{array}$ & $\begin{array}{l}\text { Ringholm S. et al., 2011; } \\
\text { Drummond MJ. et al., 2008, } \\
\text { Nielsen S. et al., 2010, } \\
\text { Mueller M. et al., 2011. }\end{array}$ \\
\hline \multirow[t]{2}{*}{ miR-1, miR-29b } & & Endurance & Russell AP. et al., 2013. \\
\hline & miR-133a, miR-378, miR-486 & $\begin{array}{l}\text { Resistance } \\
\text { exercise }\end{array}$ & Fyfe JJ. et al., 2016. \\
\hline $\begin{array}{l}\operatorname{miR}-136, \operatorname{miR}-200 c \\
\text { miR-376, miR-377, } \\
\text { miR-499b, miR-558 }\end{array}$ & $\begin{array}{l}\text { miR-28, miR-30d, miR-204, miR-330, } \\
\text { miR-345, } \\
\text { miR-375, miR-449c, miR-483, miR-509, } \\
\text { miR-520a, miR-548, miR-628, miR-653, } \\
\text { miR-670, miR-889, miR-1245a, miR-1270, } \\
\text { miR-1280, miR-1322, miR-3180 }\end{array}$ & $\begin{array}{l}\text { Chronic } \\
\text { resistance } \\
\text { exercise }\end{array}$ & Ogasawara R. et al., 2016. \\
\hline $\operatorname{miR}-451$ & miR-26a, miR-29a, miR-378 & $\begin{array}{l}\text { Resistance } \\
\text { exercise }\end{array}$ & Davidsen PK. et al., 2011. \\
\hline
\end{tabular}

The list summarize which miRNA is up-or down-regulated in skeletal muscle after physical activity.

elevated whereas miR-29b, miR-29c and miR-33 are reduced in patients affected by DM1, when compared to control individuals not presenting any pathological feature [99]. These miRNAs play roles in the regulation of muscle development [98]. Moreover, the cellular localization of miR-1, miR-133b and miR-206 seems to be scattered in DM1 muscle. Likewise, 11 miRNAs, involving the muscle enriched miRNA miR-208, are downregulated in the phosphatidylinositol-4,5-bisphosphate 3-kinase $(\mathrm{PI} 3 \mathrm{~K}) / \mathrm{AKT}$ and in the transforming growth factor- $\beta$ (TGF- $\beta$ ) signaling pathways of patient muscle samples affected by myotonic dystrophy type 2 (DM2) [100]. In fact, the downregulation of TGF- $\beta$ cascade has been involved in both inherited and acquired unhealthy status influencing skeletal muscle, and Akt2 expression is highly enhanced during skeletal muscle cell differentiation and myocyte growth, indicating an Akt2 crucial function in myogenesis [100].

Some reports linked miRNAs with several musclerelated diseases, such as Duchenne muscular dystrophy (DMD), Becker muscular dystrophy, facioscapulohumeral muscular dystrophy, limb-girdle muscular dystrophies types 2A and 2B, Miyoshi myopathy, nemaline myopathy, polymyositis, dermatomyositis, and inclusion body myositis [54, 97]. miRNAs such as miR-1, miR-21, miR-33, miR-133 and miR-206 derived from patient serum affected by Duchenne muscular dystrophy showed that specific muscle-enriched miRNAs were widely upregulated in expression related with the development of the dystrophic disease [101]. The same findings were reported in dystrophic mdx mouse muscles (these spontaneous mdx mutant mice do not express dystrophin and may be useful for studying Duchenne muscular dystrophy, they are also known as DMD), which revealed that expression levels of miR-206 were widely enhanced in the muscle when correlated with normal mouse muscles [102], indeed, miR-206 levels are elevated in the diaphragm muscle of an animal mouse model of muscular dystrophy [54]. In addition, in a murine model of skeletal-muscle hypertrophy the expression levels of miR-1 and miR-133a were reduced [54]. In murine models, these downregulations could be overcome with therapeutic treatments, such as HDAC inhibition or recovery of nitric oxide (NO) signaling [103]. In DMD derived samples, miR-31 and miR-486 were recognized as regulators of muscle regeneration. In DMD myoblasts from humans, miR-31 silencing enhances dystrophin and therefore miR-31 regulation is suggested as a probable curative approach to ameliorate the DMD phenotype [104]. miR-486 expression was not modified in patient muscles affected by Becker muscular dystrophy who displays in part functional dystrophin protein [97]. miR486 is suggested to play a significant regulatory role in the phosphatase and tensin homolog (PTEN)/Akt signaling pathway in dystrophin deficient and normal muscle [56]. miRNA expression profiling of the serum from the beaglebased canine X-linked muscular dystrophy in Japan (CXMDJ) model also demonstrated a downregulation of 
miR-1, miR-133a, and miR-206 [105]. Further analysis of serum obtained from DMD boys showed that besides three myomiRs (miR-1, miR-133a/b and miR-206) being enhanced in expression, two other muscle-enriched miRNAs, miR-208b and miR-499 raised [106]. miR-199a$5 p$ is elevated in human DMD samples when correlated to the irrespective healthy subjects. It has been showed that miR-199a-5p turns off the expression of different members of the Wnt signaling pathway, a pathway that controls satellite cell sustenance and differentiation [107].

Overall miRNA expression-profiling analysis reported that a total of 185 miRNAs were downregulated in samples of pathological muscle tissue from ten muscle diseases (Duchenne muscular dystrophy, Becker muscular dystrophy, facioscapulohumeral muscular dystrophy, limb-girdle muscular dystrophies types $2 \mathrm{~A}$ and $2 \mathrm{~B}$, Miyoshi myopathy, nemaline myopathy, polymyositis, dermatomyositis, and inclusion body myositis). Among those, five miRNAs (miR-146b, miR-221, miR-155, miR-214 and miR-222) were widely regulated by a posttranscriptional mechanism in almost all samples derived from all diseases that were examined [97, 108]. A direct genetic link has been associated to miRNA role in muscle hypertrophy $[109,110]$. An aberration responsible for the extraordinary muscularity of Texel sheep has been mapped to a single G-to-A mutation into the 3' UTR of the mRNA encoding myostatin, a component of the TGF- $\beta$ family; myostatin role is to inhibit muscle growth. This alteration generates a linking site for miR-1 and miR-206, contributing to the translational inhibition of myostatin, which phenocopies the "muscle doubling" that results from the loss of myostatin in mice, cattle and humans [110-112].

It has been reported an increase in miR-23a in skeletal muscle of patients affected by amyotrophic lateral sclerosis (ALS) when correlated to healthy subjects [113]. In vitro it was determined that miR-23a controls peroxisome proliferator-activated receptor gamma coactivator 1-alpha (PGC-1 $\alpha$ ) negatively [113], that is a fundamental stimulator of mitochondrial biogenesis and function. It has therefore been hypothesized that curative repression of miR-23a could deliver PGC- $1 \alpha$ function and improve ALS phenotype. Sixteen miRNAs such as miR-1, miR-28-5p, miR-19b, miR-100, miR127-3p miR-135, miR-192 were downregulated in patients affected by laminopathies, a class of myopathies inducing alterations in the lamin $\mathrm{A} / \mathrm{C}$ gene [114]. Pathway enrichment analysis in the predicted targets of these miRNAs revealed pathways involved in muscle repair, such as MAPK, TGF- $\beta$ and Wnt signaling. miR-100, miR-192 and miR-135, were involved in $\mathrm{C} 2 \mathrm{C} 12$ myoblast growth and differentiation. In children muscle affecting by dermatomyositis, it was observed that 33 miRNAs resulted elevated [97], miR-126 was significantly decreased in subjects in the first stage of pathology when related to control subjects [115] and it has been suggested to play a particular function in the first but not in the last stage of juvenile dermatomyositis by contributing to the expression of the vascular cell adhesion molecule 1 (VCAM-1), a protein usually demonstrated in the progression but not in the complete muscle fibers.

Facioscapulohumeral muscular dystrophy (FSHD) is due to genetic modifications including the long (q) arm of chromosome 4. This disorder derives from modifications in a region of DNA close to chromosome termination known as D4Z4. Hypermethylation of the D4Z4 region usually keeps a gene named DUX4 that is repressed in most adult cells and tissues. The DUX4 gene is placed in the segment of the D4Z4 region near to the final part of chromosome 4 [116].

The expression of the transcription factor DUX4 and its transcriptional regulation have been reported to play an important downregulation of miRNAs during FSHD disorder progression [117]. The upregulation of miRNA-411 in FSHD myoblasts has been described as a possible process for the interruption of myogenic differentiation through direct suppression of transcriptional repressor protein YAF2 and YY1 transcriptional role [118]. Full transcriptome study of miRNAs dysregulated in FSHD myoblasts and serum from FSHD patients reported an important enhance in expression of the muscle myomiRs (miR-1, miR-133a/b, miR-206) with important downregulation of different miRNAs [116]. Next-generation sequencing of FSHD myoblasts (RNA samples extracted from muscle cells) reported several additionally dysregulated miRNAs when compared with unaffected patient myoblasts, such as miR-1, miR-133a/b and miR-206 [119].

The downregulation of myogenic and non-myogenic signaling cascades that happen in the FSHD disorder status [120] is related to miRNA alterations and influence FSHD disease progression.

miRNAs are fundamental in the control of several gene networks and signaling cascades in muscle, therefore, they are significant regulators of skeletal muscle health and several miRNAs are downregulated in specific muscle disorders status [121]. Based on the results obtained in these studies, miRNAs such as, miR-1, miR-133a/b, miR206 could be considered as key regulator in this kind of dystrophy [116].

miRNAs have been identified in most biofluids, such as serum and plasma and there is a rising interest in analyzing circulating miRNAs (c-miRNA) as biomarkers of normal or pathological mechanisms [122, 123]. Controlling the status of skeletal muscle has been a longtime concern and there is constant, ongoing research to find new blood markers of muscle damage [123]. Data published shows that miRNAs are consistent biomarkers of both acute and chronic muscle injury and may be a result of adaptation to physical activity [123]. Several applications could result in both research and medical field [123]. Physical activity physiology and sports 
science could take advantage from novel biomarkers able to analyze muscle conditions in response to exercise [123]. MyomiRs can also reflect muscle mass or muscle loss. Muscle wasting is a mechanism and muscle mass a symptom; since both can often determine morbidity or mortality, circulating myomiRs are hopefully novel diagnostic/prognostic instruments to be used in the medical field [123]. Different myomiRs have been identified in skeletal muscle as well as in cardiac muscle [123]. It has been reported that several muscle-specific miRNAs, including miR-1/206, miR-133 and miR-208 are fundamental for normal myoblast differentiation and growth and they have also been involved in several cardiac and skeletal muscular disorders suggesting that miRNAbased gene approaches could have a prospective for the cure of cardiac and skeletal muscle diseases [124].

\section{SKELETAL MUSCLE REGENERATION AND AGING}

In our modern society aging is one of the important challenges. Advanced adult age is associated with changes in many physiologic systems. Of particular interest is the musculoskeletal system because it directly contributes to mobility and functional independence. Skeletal muscle mass and strength decline with age [125]. These changes are mostly due to a decrease in the quantity of muscle fibers and cellular and molecular changes that reduce the force-generation process [23].

In aging, bone mass and architecture are compromised and may result in fractures as well as tendons and ligaments undergo significant biochemical alterations that directly compromise their biomechanical function [126].

The age-related reduction in muscle repair efficiency contributes to the development of sarcopenia, one of the most important factors of disability in elderly people. During aging, several tissues undergo modifications in stem cell number and fuction, that impact tissue homeostasis. Specific extrinsic mediators from local and systemic environment are necessary for stem cell role. Aging of the stem cell either in local and systemic environment is related to stem cell death. Since the first evidence that muscle restore was under the control of soluble components present in serum, modifications in the content of the systemic environment has been the predominant model to identify impairments in skeletal muscle restore during aging [127].

In studies using old mice, muscle restore is blunted in wide part for satellite cell dysfunction [128, 129].

In other types of stem cells, such as hematopoietic stem cells, not only the role but also the quantity of satellite cells decrease with aging. In aged muscle, the quantity of stem cells could be reduced during the regeneration process [130]. It seems that there is a minimum number of muscle stem cells to effectively restore muscle mass and the quantity will be due to the fitness of the cells and the environmental support. With age, Notch pathway stimulation becomes defective for reduced delta ligand expression in myofibers and in satellite cells. This decrease in Notch stimulation is also expanded by excess of TGF- $\beta /$ phospho-Smad (pSmad), leading to an aggregation of cyclin-dependent kinase (CDK) inhibitors in muscle stem cells, hence avoiding their regenerative responses [131, 132]. Parabiosis and all muscle grafting experiments revealed that processes regulating the regeneration ability of stem cells may be particularly due to modifications of the local environment during aging [130]. In elder population indeed, the efficacy of muscle regeneration decrease, promoting that the satellite cells function and their progeny may be altered. Satellite cells are not isolated but are rather encircled and affected by several extrinsic components that are in connection with the stem cell and the stem cell niche, autocrine and paracrine elements (both at rest and after injury) and with circulating elements that can modify their function. These elements probable modify during aging and induce both reversible and irreversible modifications to the satellite cells and on their proliferating progeny.

\section{Age-associated miRNA regulation in skeletal muscle}

Sarcopenia, the age-related wasting of skeletal mass and role, enhances falls and fractures worsening the independency of life [133]. Analysis are ongoing with a larger sample size to determine if the age-related modifications in skeletal muscle are affected by miRNA aberrant expression and activity. Moreover, it will be significant with regard to the prospective of exercise levels and nutritional conditions, to consider all elements which can affect muscle miRNA levels, when comparing young and older individuals. It has been reported high levels of pri-miR-1-1, -1-2, -133a-1 and -133a-2, with no modification in pri-miR-206 in skeletal muscle biopsies taken from six aged ( $70 \pm 2$ years) subjects when related with six young (29 \pm 2 years) men [88]. The potential of miRNAs to modulate aging in model organisms has recently attracted the interest of the molecular genetics community [134]. Numerous miRNAs, such as miR-71 in C. elegans and miR-17-92 in mammals, have been demonstrated to be particularly up- or down-regulated in aging $[135,136]$. These advancements have given a further comprehension of specific elements that regulate aging signaling pathways in different species from C. elegans to humans. Interestingly, let-7 miRNA [137] is downregulated with age in C. elegans [135, 138]. Indeed, analysis in older individuals have determined that two miRNA levels from the let-7 family of miRNAs, let-7b and let-7e, are higher in skeletal muscle when correlated to young participants $[88,139]$. The sequence of $\mathrm{C}$. elegans (cel)-let-7 differs poorly from human (hsa)-let-7b 
and hsa-let-7e and this discrepancy could be enough to give various mRNA targets for these three miRNAs. In both $\mathrm{C}$. elegans and humans the role of the let-7 family of miRNAs is similar. The primary function of the let7 miRNAs seems to be anti-proliferative, as identified in human tumor cells [140-144] and in mouse neuronal stem cells [141]. The increase of let- 7 miRNAs could be the reason for the damaged capacity to stimulate and induce the proliferation of satellite cells in the elderly skeletal muscle, hence leading to the mitigated skeletal muscle regenerative ability in the aged [145]. Therefore, bioinformatic studies detected cell cycle control and cell cycle progression and proliferation as the cellular mechanisms probable to be modulated in humans by the 2 let-7 miRNAs.

Atrophy of skeletal muscles can origin from either primary or secondary muscle diseases or from inactivity and/or aging in healthy subjects [146, 147].

Analysis made at bed rest on healthy human subjects, as well as animals atrophy models (mouse and rat), demonstrated a dysregulation of myomiRs, which not contribute to inhibition of pathways such as insulin signaling, TNF, TGF- $\beta$ Smad2, and MAPK inducing progression of atrophy, insulin resistance, and metabolism and fiber type shift $[87,97,147,148]$.

To distinguish among miRNA modifications in "normal" and disorder-induced muscle atrophy, it is fundamental to correlate both mechanisms. In healthy subjects, skeletal muscle atrophy derives from continued immobility, aging, caloric limitation, physical passivity, or particular microgravity status, such as space flight and is represented by decreased muscle force, lower synthesis and higher protein degradation rate, protein carbonylation, shift in muscle fiber type from slow type I to fast type II, enhanced oxidative stress, development of insulin resistance, and intramuscular fat deposits [149]. It was demonstrated that age affects myomiR expression in an analysis correlating skeletal muscle biopsies of young and older healthy men [139]. In older men, let-7a/b/e/f and miR-25, miR-98, miR-195, and miR-1268 were increased, whereas miR-22, miR-24, miR-27a, miR-27b, miR-30d, miR-133a, miR-133b, miR-223, and miR-278 were dysregulated when compared to young participants [139]. There was no difference in the expression of miR206 among these cohorts.

\section{CONCLUSIONS}

The emergence of the miRNA field contributes to a sensational possibility to deepen the knowledge of molecular components which regulate skeletal muscle development, regeneration and aging. Moreover, miRNA biology also provides an avenue to dissect the mechanisms which may contribute to genetic and acquired muscle diseases and related complications. The impact of behavioural choices influencing physical activity has an important role in determing our longevity and quality of life. The observations that physical exercise may influence miRNA levels has important implications to understand how to maintain health throughout the lifespan, an issue of great relevance considering our aging and sedentary communities. A downregulation of different miRNAs occurs in myopathies, in chronic disorders associated to muscle loss as well as in aging. These studies suggested that skeletal muscle miRNAs play an important function in muscle adaptation or maladaptation to endurance and resistance exercise training. The recognition of miRNAs and their modulation following physical activity suggest that they could be helpful biomarkers of healthy status and might be amenable for future therapeutic intervention.

\section{ACKNOWLEDGMENTS}

This work was supported by a MIUR FIRB 2010 grant to Silvano Capitani (RBAP10Z7FS_002), by a MIUR PRIN-2009 grant to Silvano Capitani and by current research funds to Giorgio Zauli and Luca Maria Neri (FAR, FIR).

\section{CONFLICTS OF INTEREST}

The authors declare that they have no conflicts of interest.

\section{REFERENCES}

1. Jensen J, Rustad PI, Kolnes AJ, Lai YC. The role of skeletal muscle glycogen breakdown for regulation of insulin sensitivity by exercise. Front Physiol. 2011; 2:112. https:// doi.org/10.3389/fphys.2011.00112.

2. Ceccarelli G, Benedetti L, Arcari ML, Carubbi C, Galli D. Muscle stem cell and physical activity: what point is the debate at? Open Med (Wars). 2017; 12:144-56. https://doi. org/10.1515/med-2017-0022.

3. Brioche T, Kireev RA, Cuesta S, Gratas-Delamarche A, Tresguerres JA, Gomez-Cabrera MC, Vina J. Growth hormone replacement therapy prevents sarcopenia by a dual mechanism: improvement of protein balance and of antioxidant defenses. J Gerontol A Biol Sci Med Sci. 2014; 69:1186-98. https://doi.org/10.1093/gerona/glt187.

4. Bazgir B, Fathi R, Rezazadeh Valojerdi M, Mozdziak P, Asgari A. Satellite cells contribution to exercise mediated muscle hypertrophy and repair. Cell J. 2017; 18:473-84.

5. Pallafacchina G, Blaauw B, Schiaffino S. Role of satellite cells in muscle growth and maintenance of muscle mass. Nutr Metab Cardiovasc Dis. 2013; 23:S12-18. https://doi. org/10.1016/j.numecd.2012.02.002.

6. Condello G, Ling FC, Bianco A, Chastin S, Cardon G, Ciarapica D, Conte D, Cortis C, De Craemer M, Di Blasio A, Gjaka M, Hansen S, Holdsworth M, et al. Using concept 
mapping in the development of the EU-PAD framework (EUropean-Physical Activity Determinants across the life course): a DEDIPAC-study. BMC Public Health. 2016; 16:1145. https://doi.org/10.1186/s12889-016-3800-8.

7. Warburton DE, Nicol CW, Bredin SS. Prescribing exercise as preventive therapy. CMAJ. 2006; 174:961-74. https:// doi.org/10.1503/cmaj.1040750.

8. Altana V, Geretto M, Pulliero A. MicroRNAs and physical activity. Microrna. 2015; 4:74-85. https://doi.org/10.2174/ 2211536604666150813152450.

9. Catalanotto C, Cogoni C, Zardo G. MicroRNA in control of gene expression: an overview of nuclear functions. Int J Mol Sci. 2016; 17:1712. https://doi.org/10.3390/ijms17101712.

10. Silva GJ, Bye A, El Azzouzi H, Wisloff U. MicroRNAs as important regulators of exercise adaptation. Prog Cardiovasc Dis. 2017; 60:130-51. https://doi.org/10.1016/j. pcad.2017.06.003.

11. Mohan A, Asakura A. CDK inhibitors for muscle stem cell differentiation and self-renewal. J Phys Fit Sports Med. 2017; 6:65-74. https://doi.org/10.7600/jpfsm.6.65.

12. Tucker WJ, Nelson MD, Beaudry RI, Halle M, Sarma S, Kitzman DW, Gerche A, Haykowksy MJ. Impact of exercise training on peak oxygen uptake and its determinants in heart failure with preserved ejection fraction. Card Fail Rev. 2016; 2:95-101. https://doi.org/10.15420/cfr.2016:16:2.

13. He J, Wang F, Zhang P, Li W, Wang J, Li J, Liu H, Chen X. miR-491 inhibits skeletal muscle differentiation through targeting myomaker. Arch Biochem Biophys. 2017; 625626:30-38. https://doi.org/10.1016/j.abb.2017.05.020.

14. Ju H, Yang Y, Sheng A, Jiang X. Role of microRNAs in skeletal muscle development and rhabdomyosarcoma. Mol Med Rep. 2015; 11:4019-24. https://doi.org/10.3892/ mmr.2015.3275.

15. Pon JR, Marra MA. MEF2 transcription factors: developmental regulators and emerging cancer genes. Oncotarget. 2016; 7:2297-312. https://doi.org/10.18632/ oncotarget.6223.

16. Parker MG, Bennett MJ, Hieb MA, Hollar AC, Roe AA. Strength response in human femoris muscle during 2 neuromuscular electrical stimulation programs. J Orthop Sports Phys Ther. 2003; 33:719-26. https://doi.org/10.2519/ jospt.2003.33.12.719.

17. Sambasivan R, Tajbakhsh S. Skeletal muscle stem cell birth and properties. Semin Cell Dev Biol. 2007; 18:870-82. https://doi.org/10.1016/j.semcdb.2007.09.013.

18. Karalaki M, Fili S, Philippou A, Koutsilieris M. Muscle regeneration: cellular and molecular events. In Vivo. 2009; 23:779-96.

19. Tidball JG. Mechanisms of muscle injury, repair, and regeneration. Compr Physiol. 2011; 1:2029-62. https://doi. org/10.1002/cphy.c100092.

20. Gao CQ, Xu YL, Jin CL, Hu XC, Li HC, Xing GX, Yan HC, Wang XQ. Differentiation capacities of skeletal muscle satellite cells in Lantang and Landrace piglets.
Oncotarget. 2017; 8:43192-200. https://doi.org/10.18632/ oncotarget. 17860 .

21. Mauro A. Satellite cell of skeletal muscle fibers. J Biophys Biochem Cytol. 1961; 9:493-95. https://doi.org/10.1083/ jcb.9.2.493.

22. Yin H, Pasut A, Soleimani VD, Bentzinger CF, Antoun G, Thorn S, Seale P, Fernando P, van Ijcken W, Grosveld F, Dekemp RA, Boushel R, Harper ME, Rudnicki MA. MicroRNA-133 controls brown adipose determination in skeletal muscle satellite cells by targeting Prdm16. Cell Metab. 2013; 17:210-24. https://doi.org/10.1016/j. cmet.2013.01.004.

23. Kadi F, Charifi N, Denis C, Lexell J. Satellite cells and myonuclei in young and elderly women and men. Muscle Nerve. 2004; 29:120-27. https://doi.org/10.1002/ mus. 10510.

24. Lepper C, Partridge TA, Fan CM. An absolute requirement for Pax7-positive satellite cells in acute injury-induced skeletal muscle regeneration. Development. 2011; 138:3639-46. https://doi.org/10.1242/dev.067595.

25. Sambasivan R, Yao R, Kissenpfennig A, Van Wittenberghe L, Paldi A, Gayraud-Morel B, Guenou H, Malissen B, Tajbakhsh S, Galy A. Pax7-expressing satellite cells are indispensable for adult skeletal muscle regeneration. Development. 2011; 138:3647-56. https://doi.org/10.1242/ dev.067587.

26. von Maltzahn J, Jones AE, Parks RJ, Rudnicki MA. Pax7 is critical for the normal function of satellite cells in adult skeletal muscle. Proc Natl Acad Sci USA. 2013; 110:16474-79. https://doi.org/10.1073/pnas.1307680110.

27. Brack AS, Rando TA. Tissue-specific stem cells: lessons from the skeletal muscle satellite cell. Cell Stem Cell. 2012; 10:504-14. https://doi.org/10.1016/j.stem.2012.04.001.

28. Yablonka-Reuveni Z. The skeletal muscle satellite cell: still young and fascinating at 50. J Histochem Cytochem. 2011; 59:1041-59. https://doi.org/10.1369/0022155411426780.

29. Lima AR, Pagan LU, Damatto RL, Cezar MD, Bonomo C, Gomes MJ, Martinez PF, Guizoni DM, Campos DH, Damatto FC, Okoshi K, Okoshi MP. Effects of growth hormone on cardiac remodeling and soleus muscle in rats with aortic stenosis-induced heart failure. Oncotarget. 2017; 8:83009-21. https://doi.org/10.18632/oncotarget.20583.

30. Metaxas TI, Mandroukas A, Vamvakoudis E, Kotoglou K, Ekblom B, Mandroukas K. Muscle fiber characteristics, satellite cells and soccer performance in young athletes. J Sports Sci Med. 2014; 13:493-501.

31. Guo BS, Cheung KK, Yeung SS, Zhang BT, Yeung EW. Electrical stimulation influences satellite cell proliferation and apoptosis in unloading-induced muscle atrophy in mice. PLoS One. 2012; 7:e30348. https://doi.org/10.1371/journal. pone. 0030348 .

32. Snijders T, Res PT, Smeets JS, van Vliet S, van Kranenburg J, Maase K, Kies AK, Verdijk LB, van Loon LJ. Protein ingestion before sleep increases muscle mass and strength 
gains during prolonged resistance-type exercise training in healthy young men. J Nutr. 2015; 145:1178-84. https://doi. org/10.3945/jn.114.208371.

33. Porter C, Reidy PT, Bhattarai N, Sidossis LS, Rasmussen BB. Resistance exercise training alters mitochondrial function in human skeletal muscle. Med Sci Sports Exerc. 2015; 47:1922-31. https://doi.org/10.1249/ MSS.0000000000000605.

34. Petriz BA, Gomes CP, Almeida JA, de Oliveira GP Jr, Ribeiro FM, Pereira RW, Franco OL. The effects of acute and chronic exercise on skeletal muscle proteome. J Cell Physiol. 2017; 232:257-69. https://doi.org/10.1002/ jcp. 25477 .

35. Burniston JG, Hoffman EP. Proteomic responses of skeletal and cardiac muscle to exercise. Expert Rev Proteomics. 2011; 8:361-77. https://doi.org/10.1586/epr.11.17.

36. Groennebaek T, Vissing K. Impact of resistance training on skeletal muscle mitochondrial biogenesis, content, and function. Front Physiol. 2017; 8:713. https://doi. org/10.3389/fphys.2017.00713.

37. Morici G, Gruttad'Auria CI, Baiamonte P, Mazzuca E, Castrogiovanni A, Bonsignore MR. Gruttad'Auria CI, Baiamonte P, Mazzuca E, Castrogiovanni A, Bonsignore MR. Endurance training: is it bad for you? Breathe (Sheff). 2016; 12:140-47. https://doi. org/10.1183/20734735.007016.

38. Kurosaka M, Naito H, Ogura Y, Machida S, Katamoto $\mathrm{S}$. Satellite cell pool enhancement in rat plantaris muscle by endurance training depends on intensity rather than duration. Acta Physiol (Oxf). 2012; 205:159-66. https:// doi.org/10.1111/j.1748-1716.2011.02381.x.

39. Reza MM, Subramaniyam N, Sim CM, Ge X, Sathiakumar D, McFarlane C, Sharma M, Kambadur R. Irisin is a promyogenic factor that induces skeletal muscle hypertrophy and rescues denervation-induced atrophy. Nat Commun. 2017; 8:1104. https://doi.org/10.1038/s41467-017-01131-0.

40. Gandolfi M, Smania N, Vella A, Picelli A, Chirumbolo S. Assessed and emerging biomarkers in stroke and training-mediated stroke recovery: state of the art. Neural Plast. 2017; 2017:1389475. https://doi. org/10.1155/2017/1389475.

41. So B, Kim HJ, Kim J, Song W. Exercise-induced myokines in health and metabolic diseases. Integr Med Res. 2014; 3:172-79. https://doi.org/10.1016/j.imr.2014.09.007.

42. Munoz-Canoves P, Scheele C, Pedersen BK, Serrano AL. Interleukin-6 myokine signaling in skeletal muscle: a double-edged sword? FEBS J. 2013; 280:4131-48. https:// doi.org/10.1111/febs.12338.

43. Folland JP, Williams AG. The adaptations to strength training : morphological and neurological contributions to increased strength. Sports Med. 2007; 37:145-68. https:// doi.org/10.2165/00007256-200737020-00004.

44. Spiering BA, Kraemer WJ, Anderson JM, Armstrong LE, Nindl BC, Volek JS, Maresh CM. Resistance exercise biology: manipulation of resistance exercise programme variables determines the responses of cellular and molecular signalling pathways. Sports Med. 2008; 38:527-40. https:// doi.org/10.2165/00007256-200838070-00001.

45. Moore DR, Atherton PJ, Rennie MJ, Tarnopolsky MA, Phillips SM. Resistance exercise enhances mTOR and MAPK signalling in human muscle over that seen at rest after bolus protein ingestion. Acta Physiol (Oxf). 2011; 201:365-72. https://doi. org/10.1111/j.1748-1716.2010.02187.x.

46. Fell J, Williams D. The effect of aging on skeletal-muscle recovery from exercise: possible implications for aging athletes. J Aging Phys Act. 2008; 16:97-115. https://doi. org/10.1123/japa.16.1.97.

47. Seene T, Kaasik P, Umnova M. Structural rearrangements in contractile apparatus and resulting skeletal muscle remodelling: effect of exercise training. J Sports Med Phys Fitness. 2009; 49:410-23.

48. Hardie DG, Sakamoto K. AMPK: a key sensor of fuel and energy status in skeletal muscle. Physiology (Bethesda). 2006; 21:48-60. https://doi.org/10.1152/ physiol.00044.2005.

49. McGee SL, van Denderen BJ, Howlett KF, Mollica J, Schertzer JD, Kemp BE, Hargreaves M. AMP-activated protein kinase regulates GLUT4 transcription by phosphorylating histone deacetylase 5. Diabetes. 2008; 57:860-67. https://doi.org/10.2337/db07-0843.

50. Llano-Diez M, Renaud G, Andersson M, Marrero HG, Cacciani N, Engquist H, Corpeno R, Artemenko K, Bergquist J, Larsson L. Mechanisms underlying ICU muscle wasting and effects of passive mechanical loading. Crit Care. 2012; 16:R209. https://doi.org/10.1186/cc11841.

51. Mok GF, Lozano-Velasco E, Munsterberg A. microRNAs in skeletal muscle development. Semin Cell Dev Biol. 2017; 72:67-76. https://doi.org/10.1016/j.semcdb.2017.10.032.

52. Zhu Y, Zong L, Mei L, Zhao HB. Connexin26 gap junction mediates miRNA intercellular genetic communication in the cochlea and is required for inner ear development. Sci Rep. 2015; 5:15647. https://doi.org/10.1038/srep15647.

53. Go AS, Mozaffarian D, Roger VL, Benjamin EJ, Berry JD, Borden WB, Bravata DM, Dai S, Ford ES, Fox CS, Franco S, Fullerton HJ, Gillespie C, et al. Heart disease and stroke statistics - 2013 update: a report from the American Heart Association. Circulation. 2013; 127:e6-e245. https://doi. org/10.1161/CIR.0b013e31828124ad.

54. McCarthy JJ, Esser KA. MicroRNA-1 and microRNA133a expression are decreased during skeletal muscle hypertrophy. J Appl Physiol (1985). 2007; 102:306-13. https://doi.org/10.1152/japplphysiol.00932.2006.

55. Callis TE, Deng Z, Chen JF, Wang DZ. Muscling through the microRNA world. Exp Biol Med (Maywood). 2008; 233:131-38. https://doi.org/10.3181/0709-MR-237.

56. Small EM, Sutherland LB, Rajagopalan KN, Wang $\mathrm{S}$, Olson EN. MicroRNA-218 regulates vascular 
patterning by modulation of Slit-Robo signaling. Circ Res. 2010; 107:1336-44. https://doi.org/10.1161/ CIRCRESAHA.110.227926.

57. Li D, Xia L, Chen M, Lin C, Wu H, Zhang Y, Pan S, Li X. miR-133b, a particular member of myomiRs, coming into playing its unique pathological role in human cancer. Oncotarget. 2017; 8:50193-208. https://doi.org/10.18632/ oncotarget. 16745 .

58. Liu N, Olson EN. MicroRNA regulatory networks in cardiovascular development. Dev Cell. 2010; 18:510-25. https://doi.org/10.1016/j.devcel.2010.03.010.

59. Rao PK, Kumar RM, Farkhondeh M, Baskerville S, Lodish HF. Myogenic factors that regulate expression of musclespecific microRNAs. Proc Natl Acad Sci USA. 2006; 103:8721-26. https://doi.org/10.1073/pnas.0602831103.

60. Rosenberg MI, Georges SA, Asawachaicharn A, Analau E, Tapscott SJ. MyoD inhibits Fstl1 and Utrn expression by inducing transcription of miR-206. J Cell Biol. 2006; 175:77-85. https://doi.org/10.1083/jcb.200603039.

61. Liu N, Williams AH, Kim Y, McAnally J, Bezprozvannaya S, Sutherland LB, Richardson JA, Bassel-Duby R, Olson EN. An intragenic MEF2-dependent enhancer directs muscle-specific expression of microRNAs 1 and 133. Proc Natl Acad Sci USA. 2007; 104:20844-49. https://doi. org/10.1073/pnas.0710558105.

62. Chen JF, Mandel EM, Thomson JM, Wu Q, Callis TE, Hammond SM, Conlon FL, Wang DZ. The role of microRNA-1 and microRNA-133 in skeletal muscle proliferation and differentiation. Nat Genet. 2006; 38:228 33. https://doi.org/10.1038/ng1725.

63. Elia L, Contu R, Quintavalle M, Varrone F, Chimenti C, Russo MA, Cimino V, De Marinis L, Frustaci A, Catalucci D, Condorelli G. Reciprocal regulation of microRNA-1 and insulin-like growth factor-1 signal transduction cascade in cardiac and skeletal muscle in physiological and pathological conditions. Circulation. 2009; 120:2377-85. https://doi.org/10.1161/CIRCULATIONAHA.109.879429.

64. Eisenberg I, Alexander MS, Kunkel LM. miRNAS in normal and diseased skeletal muscle. J Cell Mol Med. 2009; 13:2-11. https://doi.org/10.1111/j.1582-4934.2008.00524.x.

65. Yin H, Price F, Rudnicki MA. Satellite cells and the muscle stem cell niche. Physiol Rev. 2013; 93:23-67. https://doi. org/10.1152/physrev.00043.2011.

66. Proctor CJ, Goljanek-Whysall K. Using computer simulation models to investigate the most promising microRNAs to improve muscle regeneration during ageing. Sci Rep. 2017; 7:12314. https://doi.org/10.1038/ s41598-017-12538-6.

67. Safdar A, Abadi A, Akhtar M, Hettinga BP, Tarnopolsky MA. miRNA in the regulation of skeletal muscle adaptation to acute endurance exercise in C57B1/6J male mice. PLoS One. 2009; 4:e5610. https://doi.org/10.1371/journal. pone. 0005610 .
68. Lozano-Velasco E, Galiano-Torres J, Jodar-Garcia A, Aranega AE, Franco D. miR-27 and miR-125 distinctly regulate muscle-enriched transcription factors in cardiac and skeletal myocytes. Biomed Res Int. 2015; 2015:391306. https://doi.org/10.1155/2015/391306.

69. Fyfe JJ, Bartlett JD, Hanson ED, Stepto NK, Bishop DJ. Endurance training intensity does not mediate interference to maximal lower-body strength gain during short-term concurrent training. Front Physiol. 2016; 7:487. https://doi. org/10.3389/fphys.2016.00487.

70. Jing L, Jin C, Lu Y, Huo P, Zhou L, Wang Y, Tian Y. Investigation of microRNA expression profiles associated with human alcoholic cardiomyopathy. Cardiology. 2015; 130:223-33. https://doi.org/10.1159/000370028.

71. Hupkes M, Sotoca AM, Hendriks JM, van Zoelen EJ, Dechering KJ. MicroRNA miR-378 promotes BMP2induced osteogenic differentiation of mesenchymal progenitor cells. BMC Mol Biol. 2014; 15:1. https://doi. org/10.1186/1471-2199-15-1.

72. Fischer U, Ludwig N, Raslan A, Meier C, Meese E. Gene amplification during myogenic differentiation. Oncotarget. 2016; 7:6864-77. https://doi.org/10.18632/oncotarget.6845.

73. Xu T, Zhou Q, Che L, Das S, Wang L, Jiang J, Li G, Xu J, Yao J, Wang H, Dai Y, Xiao J. Circulating miR-21, miR-378, and miR-940 increase in response to an acute exhaustive exercise in chronic heart failure patients. Oncotarget. 2016; 7:12414-25. https://doi.org/10.18632/ oncotarget. 6966.

74. Zacharewicz E, Lamon S, Russell AP. MicroRNAs in skeletal muscle and their regulation with exercise, ageing, and disease. Front Physiol. 2013; 4:266. https://doi. org/10.3389/fphys.2013.00266.

75. Pasiakos SM, McClung JP. miRNA analysis for the assessment of exercise and amino acid effects on human skeletal muscle. Adv Nutr. 2013; 4:412-17. https://doi. org/10.3945/an.113.003699.

76. Davidsen PK, Gallagher IJ, Hartman JW, Tarnopolsky MA, Dela F, Helge JW, Timmons JA, Phillips SM. High responders to resistance exercise training demonstrate differential regulation of skeletal muscle microRNA expression. J Appl Physiol (1985). 2011; 110:309-17. https://doi.org/10.1152/japplphysiol.00901.2010.

77. Kirby TJ, McCarthy JJ. MicroRNAs in skeletal muscle biology and exercise adaptation. Free Radic Biol Med. 2013; 64:95-105. https://doi.org/10.1016/j. freeradbiomed.2013.07.004.

78. Gagan J, Dey BK, Layer R, Yan Z, Dutta A. MicroRNA-378 targets the myogenic repressor MyoR during myoblast differentiation. J Biol Chem. 2011; 286:19431-38. https:// doi.org/10.1074/jbc.M111.219006.

79. Carrer M, Liu N, Grueter CE, Williams AH, Frisard MI, Hulver MW, Bassel-Duby R, Olson EN. Control of mitochondrial metabolism and systemic energy homeostasis by microRNAs 378 and 378*. Proc Natl Acad 
Sci USA. 2012; 109:15330-35. https://doi.org/10.1073/ pnas. 1207605109.

80. Masi LN, Serdan TD, Levada-Pires AC, Hatanaka E, Silveira LD, Cury-Boaventura MF, Pithon-Curi TC, Curi R, Gorjao R, Hirabara SM. Regulation of gene expression by exercise-related micrornas. Cell Physiol Biochem. 2016; 39:2381-97. https://doi.org/10.1159/000452507.

81. Ceccarelli G, Fratino M, Selvaggi C, Giustini N, Serafino S, Schietroma I, Corano Scheri G, Pavone P, Passavanti G, Alunni Fegatelli D, Mezzaroma I, Antonelli G, Vullo V, et al. A pilot study on the effects of probiotic supplementation on neuropsychological performance and microRNA-29a-c levels in antiretroviral-treated HIV-1-infected patients. Brain Behav. 2017; 7:e00756. https://doi.org/10.1002/ brb3.756.

82. Russell AP, Lamon S, Boon H, Wada S, Guller I, Brown EL, Chibalin AV, Zierath JR, Snow RJ, Stepto N, Wadley GD, Akimoto T. Regulation of miRNAs in human skeletal muscle following acute endurance exercise and short-term endurance training. J Physiol. 2013; 591:4637-53. https:// doi.org/10.1113/jphysiol.2013.255695.

83. van Rooij E, Quiat D, Johnson BA, Sutherland LB, Qi X, Richardson JA, Kelm RJ Jr, Olson EN. A family of microRNAs encoded by myosin genes governs myosin expression and muscle performance. Dev Cell. 2009; 17:662-73. https://doi.org/10.1016/j.devcel.2009.10.013.

84. Margolis LM, McClung HL, Murphy NE, Carrigan CT, Pasiakos SM. Skeletal muscle myomiR are differentially expressed by endurance exercise mode and combined essential amino acid and carbohydrate supplementation. Front Physiol. 2017; 8:182. https://doi.org/10.3389/ fphys.2017.00182.

85. Mercatelli N, Fittipaldi S, De Paola E, Dimauro I, Paronetto MP, Jackson MJ, Caporossi D. MiR-23-TrxR1 as a novel molecular axis in skeletal muscle differentiation. Sci Rep. 2017; 7:7219. https://doi.org/10.1038/s41598-017-07575-0.

86. Fry CS, Kirby TJ, Kosmac K, McCarthy JJ, Peterson CA. Myogenic progenitor cells control extracellular matrix production by fibroblasts during skeletal muscle hypertrophy. Cell Stem Cell. 2017; 20:56-69. https://doi. org/10.1016/j.stem.2016.09.010.

87. Ringholm S, Bienso RS, Kiilerich K, Guadalupe-Grau A, Aachmann-Andersen NJ, Saltin B, Plomgaard P, Lundby C, Wojtaszewski JF, Calbet JA, Pilegaard H. Bed rest reduces metabolic protein content and abolishes exerciseinduced mRNA responses in human skeletal muscle. Am J Physiol Endocrinol Metab. 2011; 301:E649-58. https://doi. org/10.1152/ajpendo.00230.2011.

88. Drummond MJ, Dreyer HC, Pennings B, Fry CS, Dhanani S, Dillon EL, Sheffield-Moore M, Volpi E, Rasmussen BB. Skeletal muscle protein anabolic response to resistance exercise and essential amino acids is delayed with aging. J Appl Physiol (1985). 2008; 104:1452-61. https://doi. org/10.1152/japplphysiol.00021.2008.
89. Nielsen S, Akerstrom T, Rinnov A, Yfanti C, Scheele C, Pedersen BK, Laye MJ. The miRNA plasma signature in response to acute aerobic exercise and endurance training. PLoS One. 2014; 9:e87308. https://doi.org/10.1371/journal. pone. 0087308 .

90. Mueller M, Breil FA, Lurman G, Klossner S, Fluck M, Billeter R, Dapp C, Hoppeler H. Different molecular and structural adaptations with eccentric and conventional strength training in elderly men and women. Gerontology. 2011; 57:528-38. https://doi.org/10.1159/000323267.

91. Nielsen S, Scheele C, Yfanti C, Akerstrom T, Nielsen AR, Pedersen BK, Laye MJ. Muscle specific microRNAs are regulated by endurance exercise in human skeletal muscle. J Physiol. 2010; 588:4029-37. https://doi.org/10.1113/ jphysiol.2010.189860.

92. Keller P, Vollaard NB, Gustafsson T, Gallagher IJ, Sundberg CJ, Rankinen T, Britton SL, Bouchard C, Koch LG, Timmons JA. A transcriptional map of the impact of endurance exercise training on skeletal muscle phenotype. J Appl Physiol (1985). 2011; 110:46-59. https://doi. org/10.1152/japplphysiol.00634.2010.

93. Mitchelson KR, Qin WY. Roles of the canonical myomiRs miR-1, -133 and -206 in cell development and disease. World J Biol Chem. 2015; 6:162-208. https://doi. org/10.4331/wjbc.v6.i3.162.

94. Iwasaki H, Imamura T, Morino K, Shimosato T, Tawa M, Ugi S, Sakurai H, Maegawa H, Okamura T. MicroRNA-494 plays a role in fiber type-specific skeletal myogenesis in human induced pluripotent stem cells. Biochem Biophys Res Commun. 2015; 468:208-13. https://doi.org/10.1016/j. bbrc.2015.10.128.

95. Shen L, Chen L, Zhang S, Zhang Y, Wang J, Zhu L. MicroRNA-23a reduces slow myosin heavy chain isoforms composition through myocyte enhancer factor 2C (MEF2C) and potentially influences meat quality. Meat Sci. 2016; 116:201-06. https://doi.org/10.1016/j.meatsci.2016.02.023.

96. Ogasawara R, Akimoto T, Umeno T, Sawada S, Hamaoka T, Fujita S. MicroRNA expression profiling in skeletal muscle reveals different regulatory patterns in high and low responders to resistance training. Physiol Genomics. 2016; 48:320-24. https://doi.org/10.1152/ physiolgenomics.00124.2015.

97. Eisenberg I, Eran A, Nishino I, Moggio M, Lamperti C, Amato AA, Lidov HG, Kang PB, North KN, MitraniRosenbaum S, Flanigan KM, Neely LA, Whitney D, et al. Distinctive patterns of microRNA expression in primary muscular disorders. Proc Natl Acad Sci USA. 2007; 104:17016-21. https://doi.org/10.1073/pnas.0708115104.

98. Gambardella S, Rinaldi F, Lepore SM, Viola A, Loro E, Angelini C, Vergani L, Novelli G, Botta A. Overexpression of microRNA-206 in the skeletal muscle from myotonic dystrophy type 1 patients. J Transl Med. 2010; 8:48. https:// doi.org/10.1186/1479-5876-8-48.

99. Perbellini R, Greco S, Sarra-Ferraris G, Cardani R, Capogrossi MC, Meola G, Martelli F. Dysregulation and 
cellular mislocalization of specific miRNAs in myotonic dystrophy type 1 . Neuromuscul Disord. 2011; 21:81-88. https://doi.org/10.1016/j.nmd.2010.11.012.

100. Greco CM, Camera M, Facchinetti L, Brambilla M, Pellegrino S, Gelmi ML, Tremoli E, Corsini A, Ferri N. Chemotactic effect of prorenin on human aortic smooth muscle cells: a novel function of the (pro)renin receptor. Cardiovasc Res. 2012; 95:366-74. https://doi.org/10.1093/ cvr/cvs204.

101. Zaharieva IT, Calissano M, Scoto M, Preston M, Cirak S, Feng L, Collins J, Kole R, Guglieri M, Straub V, Bushby K, Ferlini A, Morgan JE, Muntoni F. Dystromirs as serum biomarkers for monitoring the disease severity in Duchenne muscular Dystrophy. PLoS One. 2013; 8:e80263. https:// doi.org/10.1371/journal.pone.0080263.

102. Roberts TC, Godfrey C, McClorey G, Vader P, Briggs D, Gardiner C, Aoki Y, Sargent I, Morgan JE, Wood MJ. Extracellular microRNAs are dynamic non-vesicular biomarkers of muscle turnover. Nucleic Acids Res. 2013; 41:9500-13. https://doi.org/10.1093/nar/gkt724.

103. Colussi C, Gaetano C, Capogrossi MC. AAV-dependent targeting of myostatin function: follistatin strikes back at muscular dystrophy. Gene Ther. 2008; 15:1075-76. https:// doi.org/10.1038/gt.2008.95.

104. Cacchiarelli D, Incitti T, Martone J, Cesana M, Cazzella V, Santini T, Sthandier O, Bozzoni I. miR-31 modulates dystrophin expression: new implications for Duchenne muscular dystrophy therapy. EMBO Rep. 2011; 12:136-41. https://doi.org/10.1038/embor.2010.208.

105. Mizuno H, Nakamura A, Aoki Y, Ito N, Kishi S, Yamamoto K, Sekiguchi M, Takeda S, Hashido K. Identification of muscle-specific microRNAs in serum of muscular dystrophy animal models: promising novel blood-based markers for muscular dystrophy. PLoS One. 2011; 6:e18388. https://doi.org/10.1371/journal.pone.0018388.

106. Li X, Li Y, Zhao L, Zhang D, Yao X, Zhang H, Wang YC, Wang XY, Xia H, Yan J, Ying H. Circulating musclespecific miRNAs in Duchenne muscular dystrophy patients. Mol Ther Nucleic Acids. 2014; 3:e177. https://doi. org/10.1038/mtna.2014.29.

107. Polesskaya A, Seale P, Rudnicki MA. Wnt signaling induces the myogenic specification of resident CD45+ adult stem cells during muscle regeneration. Cell. 2003; 113:841-52. https://doi.org/10.1016/S0092-8674(03)00437-9.

108. Sayed D, Abdellatif M. MicroRNAs in development and disease. Physiol Rev. 2011; 91:827-87. https://doi. org/10.1152/physrev.00006.2010.

109. Clop A, Marcq F, Takeda H, Pirottin D, Tordoir X, Bibe B, Bouix J, Caiment F, Elsen JM, Eychenne F, Larzul C, Laville E, Meish F, et al. A mutation creating a potential illegitimate microRNA target site in the myostatin gene affects muscularity in sheep. Nat Genet. 2006; 38:813-18. https://doi.org/10.1038/ng1810.
110. Deng Z, Chen JF, Wang DZ. Transgenic overexpression of miR-133a in skeletal muscle. BMC Musculoskelet Disord. 2011; 12:115. https://doi.org/10.1186/1471-2474-12-115.

111. Lee Y, Kim M, Han J, Yeom KH, Lee S, Baek SH, Kim VN. MicroRNA genes are transcribed by RNA polymerase II. EMBO J. 2004; 23:4051-60. https://doi.org/10.1038/ sj.emboj.7600385.

112. Tobin JF, Celeste AJ. Myostatin, a negative regulator of muscle mass: implications for muscle degenerative diseases. Curr Opin Pharmacol. 2005; 5:328-32. https:// doi.org/10.1016/j.coph.2005.01.011.

113. Russell AJ, Hartman JJ, Hinken AC, Muci AR, Kawas R, Driscoll L, Godinez G, Lee KH, Marquez D, Browne WF, Chen MM, Clarke D, Collibee SE, et al. Activation of fast skeletal muscle troponin as a potential therapeutic approach for treating neuromuscular diseases. Nat Med. 2012; 18:452-55. https://doi.org/10.1038/nm.2618.

114. Sylvius N, Bonne G, Straatman K, Reddy T, Gant TW, Shackleton S. MicroRNA expression profiling in patients with lamin A/C-associated muscular dystrophy. FASEB J. 2011; 25:3966-78. https://doi.org/10.1096/fj.11-182915.

115. Kim E, Cook-Mills J, Morgan G, Sredni ST, Pachman LM. Increased expression of vascular cell adhesion molecule 1 in muscle biopsy samples from juvenile dermatomyositis patients with short duration of untreated disease is regulated by miR-126. Arthritis Rheum. 2012; 64:3809-17. https:// doi.org/10.1002/art.34606.

116. Dmitriev P, Stankevicins L, Ansseau E, Petrov A, Barat A, Dessen P, Robert T, Turki A, Lazar V, Labourer E, Belayew A, Carnac G, Laoudj-Chenivesse D, et al. Defective regulation of microRNA target genes in myoblasts from facioscapulohumeral dystrophy patients. J Biol Chem. 2013; 288:34989-5002. https://doi.org/10.1074/jbc.M113.504522.

117. Cheli S, Francois S, Bodega B, Ferrari F, Tenedini E, Roncaglia E, Ferrari S, Ginelli E, Meneveri R. Expression profiling of FSHD-1 and FSHD-2 cells during myogenic differentiation evidences common and distinctive gene dysregulation patterns. PLoS One. 2011; 6:e20966. https:// doi.org/10.1371/journal.pone.0020966.

118. Harafuji N, Schneiderat P, Walter MC, Chen YW. miR411 is up-regulated in FSHD myoblasts and suppresses myogenic factors. Orphanet J Rare Dis. 2013; 8:55. https:// doi.org/10.1186/1750-1172-8-55.

119. Colangelo V, Francois S, Solda G, Picco R, Roma F, Ginelli E, Meneveri R. Next-generation sequencing analysis of miRNA expression in control and FSHD myogenesis. PLoS One. 2014; 9:e108411. https://doi.org/10.1371/journal. pone. 0108411 .

120. Tsumagari K, Chang SC, Lacey M, Baribault C, Chittur SV, Sowden J, Tawil R, Crawford GE, Ehrlich M. Gene expression during normal and FSHD myogenesis. BMC Med Genomics. 2011; 4:67. https://doi. org/10.1186/1755-8794-4-67. 
121. Deiuliis JA, Syed R, Duggineni D, Rutsky J, Rengasamy P, Zhang J, Huang K, Needleman B, Mikami D, Perry K, Hazey J, Rajagopalan S. Visceral adipose MicroRNA 223 is upregulated in human and murine obesity and modulates the inflammatory phenotype of macrophages. PLoS One. 2016; 11:e0165962. https://doi.org/10.1371/journal. pone. 0165962 .

122. De Guire V, Robitaille R, Tetreault N, Guerin R, Menard C, Bambace N, Sapieha P. Circulating miRNAs as sensitive and specific biomarkers for the diagnosis and monitoring of human diseases: promises and challenges. Clin Biochem. 2013; 46:846-60. https://doi.org/10.1016/j. clinbiochem.2013.03.015.

123. Siracusa J, Koulmann N, Banzet S. Circulating myomiRs: a new class of biomarkers to monitor skeletal muscle in physiology and medicine. J Cachexia Sarcopenia Muscle. 2018; 9:20-27. https://doi.org/10.1002/jcsm.12227.

124. Huang ZP, Neppl RL Jr, Wang DZ. Application of microRNA in cardiac and skeletal muscle disease gene therapy. Methods Mol Biol. 2011; 709:197-210. https://doi. org/10.1007/978-1-61737-982-6_12.

125. Gomes MJ, Martinez PF, Pagan LU, Damatto RL, Cezar MD, Lima AR, Okoshi K, Okoshi MP. Skeletal muscle aging: influence of oxidative stress and physical exercise. Oncotarget. 2017; 8:20428-40. https://doi.org/10.18632/ oncotarget.14670.

126. Frontera WR. What is it about old muscles? J Physiol. 2017; 595:4581-82. https://doi.org/10.1113/JP274541.

127. Conboy MJ, Conboy IM, Rando TA. Heterochronic parabiosis: historical perspective and methodological considerations for studies of aging and longevity. Aging Cell. 2013; 12:525-30. https://doi.org/10.1111/acel.12065.

128. Chakkalakal JV, Jones KM, Basson MA, Brack AS. The aged niche disrupts muscle stem cell quiescence. Nature. 2012; 490:355-60. https://doi.org/10.1038/nature11438.

129. Sousa-Victor P, Perdiguero E, Munoz-Canoves P. Geroconversion of aged muscle stem cells under regenerative pressure. Cell Cycle. 2014; 13:3183-90. https://doi.org/10.4161/15384101.2014.965072.

130. Brack AS, Munoz-Canoves P. The ins and outs of muscle stem cell aging. Skelet Muscle. 2016; 6:1. https://doi. org/10.1186/s13395-016-0072-z.

131. Conboy IM, Conboy MJ, Smythe GM, Rando TA. Notch-mediated restoration of regenerative potential to aged muscle. Science. 2003; 302:1575-77. https://doi. org/10.1126/science. 1087573 .

132. Carlson RE, Kirby BS, Voyles WF, Dinenno FA. Evidence for impaired skeletal muscle contraction-induced rapid vasodilation in aging humans. Am J Physiol Heart Circ Physiol. 2008; 294:H1963-70. https://doi.org/10.1152/ ajpheart.01084.2007.

133. Ferrucci L, Baroni M, Ranchelli A, Lauretani F, Maggio M, Mecocci P, Ruggiero C. Interaction between bone and muscle in older persons with mobility limitations. Curr
Pharm Des. 2014; 20:3178-97. https://doi.org/10.2174/13 816128113196660690 .

134. Vidal M, Cusick ME, Barabasi AL. Interactome networks and human disease. Cell. 2011; 144:986-98. https://doi. org/10.1016/j.cell.2011.02.016.

135. de Lencastre A, Pincus Z, Zhou K, Kato M, Lee SS, Slack FJ. MicroRNAs both promote and antagonize longevity in C. elegans. Curr Biol. 2010; 20:2159-68. https://doi. org/10.1016/j.cub.2010.11.015.

136. Grillari J, Hackl M, Grillari-Voglauer R. miR-17-92 cluster: ups and downs in cancer and aging. Biogerontology. 2010; 11:501-06. https://doi.org/10.1007/s10522-010-9272-9.

137. Guo M, Zhao X, Yuan X, Jiang J, Li P. MiR-let-7a inhibits cell proliferation, migration, and invasion by downregulating PKM2 in cervical cancer. Oncotarget. 2017; 8:28226-36. https://doi.org/10.18632/oncotarget.15999.

138. Ibanez-Ventoso C, Yang M, Guo S, Robins H, Padgett RW, Driscoll M. Modulated microRNA expression during adult lifespan in Caenorhabditis elegans. Aging Cell. 2006; 5:23546. https://doi.org/10.1111/j.1474-9726.2006.00210.x.

139. Drummond MJ, McCarthy JJ, Sinha M, Spratt HM, Volpi E, Esser KA, Rasmussen BB. Aging and microRNA expression in human skeletal muscle: a microarray and bioinformatics analysis. Physiol Genomics. 2011; 43:595-603. https://doi. org/10.1152/physiolgenomics.00148.2010.

140. Johnson CD, Esquela-Kerscher A, Stefani G, Byrom M, Kelnar K, Ovcharenko D, Wilson M, Wang X, Shelton J, Shingara J, Chin L, Brown D, Slack FJ. The let-7 microRNA represses cell proliferation pathways in human cells. Cancer Res. 2007; 67:7713-22. https://doi.org/10.1158/0008-5472. CAN-07-1083.

141. Nishino J, Kim I, Chada K, Morrison SJ. Hmga2 promotes neural stem cell self-renewal in young but not old mice by reducing p16Ink4a and p19Arf Expression. Cell. 2008; 135:227-39. https://doi.org/10.1016/j.cell.2008.09.017.

142. Dong Q, Meng P, Wang T, Qin W, Qin W, Wang F, Yuan J, Chen Z, Yang A, Wang H. MicroRNA let-7a inhibits proliferation of human prostate cancer cells in vitro and in vivo by targeting E2F2 and CCND2. PLoS One. 2010; 5:e10147. https://doi.org/10.1371/journal.pone.0010147.

143. Zhao Z, Boyle TJ, Liu Z, Murray JI, Wood WB, Waterston RH. A negative regulatory loop between microRNA and Hox gene controls posterior identities in Caenorhabditis elegans. PLoS Genet. 2010; 6:e1001089. https://doi. org/10.1371/journal.pgen.1001089.

144. Lee ST, Chu K, Oh HJ, Im WS, Lim JY, Kim SK, Park CK, Jung KH, Lee SK, Kim M, Roh JK. Let-7 microRNA inhibits the proliferation of human glioblastoma cells. J Neurooncol. 2011; 102:19-24. https://doi.org/10.1007/ s11060-010-0286-6.

145. Carlson ME, Suetta C, Conboy MJ, Aagaard P, Mackey A, Kjaer M, Conboy I. Molecular aging and rejuvenation of human muscle stem cells. EMBO Mol Med. 2009; 1:38191. https://doi.org/10.1002/emmm.200900045. 
146. Rudrappa SS, Wilkinson DJ, Greenhaff PL, Smith K, Idris I, Atherton PJ. Human Skeletal Muscle Disuse Atrophy: Effects on Muscle Protein Synthesis, Breakdown, and Insulin Resistance-A Qualitative Review. Front Physiol. 2016; 7:361. https://doi.org/10.3389/fphys.2016.00361.

147. Kovanda A, Rezen T, Rogelj B. MicroRNA in skeletal muscle development, growth, atrophy, and disease. Wiley Interdiscip Rev RNA. 2014; 5:509-25. https://doi. org/10.1002/wrna.1227.

148. McCarthy JJ, Esser KA, Peterson CA, Dupont-Versteegden EE. Evidence of MyomiR network regulation of betamyosin heavy chain gene expression during skeletal muscle atrophy. Physiol Genomics. 2009; 39:219-26. https://doi. org/10.1152/physiolgenomics.00042.2009.
149. Alibegovic AC, Sonne MP, Hojbjerre L, Bork-Jensen J, Jacobsen S, Nilsson E, Faerch K, Hiscock N, Mortensen B, Friedrichsen M, Stallknecht B, Dela F, Vaag A. Insulin resistance induced by physical inactivity is associated with multiple transcriptional changes in skeletal muscle in young men. Am J Physiol Endocrinol Metab. 2010; 299:E752-63. https://doi.org/10.1152/ajpendo.00590.2009. 